\title{
The environmental impact of nutrition transition in three case study countries
}

\author{
Margaret Gill $^{1}$ - Diana Feliciano ${ }^{1} \cdot$ Jennie Macdiarmid $^{2} \cdot$ Pete Smith $^{1}$
}

Received: 21 January 2015 / Accepted: 18 March 2015 / Published online: 12 April 2015

(C) The Author(s) 2015. This article is published with open access at Springerlink.com

\begin{abstract}
This paper explores the environmental impacts of dietary changes consistent with the nutrition transition common in countries going through economic development, inferred from commodity supply data from FAOSTAT. Supply data for 1961 and 2011 from three case study countries which have undergone significant economic transition in recent decades (Brazil, China and India) were compared on a per-capita basis to avoid confounding issues of population growth. Brazil showed marked increases in beef and poultry meat supply (kcal) while in China poultry and pig meat showed marked increases, particularly for pig meat. Per-capita supply of fruit in Brazil and vegetables in China were higher than in Europe by 2011. Supply of vegetable oil increased in all three countries and this was the majority commodity traded, hence much of its impact would have been felt in country of origin. The increase in beef production in Brazil, attributed to changing diet (2001-2011), had the greatest impact on increased water use, although the increase in supply of pig meat in China and cereals in China and India (attributable to changing diets) also made major contributions. The increase in cereal supply in China and India had a major impact on phosphorus and nitrogen cycles, with beef having a major impact on greenhouse gas emissions (GHGs). The increase in vegetable oils had a major impact through increasing land use. These findings
\end{abstract}

Special section series Strengthening the links between nutrition and health outcomes and agricultural research

Margaret Gill

m.gill@abdn.ac.uk

1 Institute of Biological \& Environmental Sciences, 23 St Machar Drive, Aberdeen AB24 3UU, UK

2 Rowett Institute for Nutrition and Health, University of Aberdeen, Aberdeen AB25 2ZD, UK highlight differential environmental impacts of the nutrition transition in different countries and emphasise the need to measure environmental impacts beyond those on GHGs.

Keywords Environmental impacts · Nutrition transition · China $\cdot$ Brazil $\cdot$ India

\section{Introduction}

The observation that diets change as countries develop economically, socially and politically is well recognised and termed 'nutrition transition' (Popkin 2003). Dietary changes are typically from traditional diets (which vary between countries) to diets high in sugar, fat, animal based products and processed foods, and low in fibre and unrefined cereals - diets characteristic of high income countries. The driving forces behind these changes have been attributed to increasing wealth, the availability and access to cheaper food, expansion of global food markets and urbanisation (Popkin 2003). Changes to food systems and diets, along with reduced physical activity, have resulted in a global increase in the prevalence of people overweight and obese, and in noncommunicable diseases (NCD), such as diabetes, cardiovascular disease and cancer. Globally the prevalence of overweight and obese individuals (BMI $\geq 25 \mathrm{~kg} . \mathrm{m}^{-2}$ ) has increased among adults from $27.5 \%$ in 1980 to $47.1 \%$ in 2013 (Stevens et al. 2012), with increases seen in both developed and developing countries, and among adults and children $(\mathrm{Ng}$ et al. 2014). It is estimated that between 1980 and 2008, the global prevalence of obesity $\left(\mathrm{BMI} \geq 30 \mathrm{~kg} \cdot \mathrm{m}^{-2}\right)$ almost doubled, with the fastest rate of increase observed between 1992 and 2002.

While higher intakes of sugars, fats and processed foods are contributing to obesity and $\mathrm{NCD}$, some of the dietary changes can have health benefits in populations where 
malnutrition is common, specifically in terms of micronutrient status. For example, a small increase in animal based products (e.g. meat and dairy) can provide essential micronutrients, such as iron, zinc, B-vitamins and calcium, which are often deficient in the diets in low and middle income countries. There is, however, a fine line in the nutrition transition between ensuring nutrient adequacy while avoiding excessive consumption. In the case of red meat, while it can provide essential micronutrients, it tends to be high in fats, especially saturated fatty acids. Consumption of meat tends to increase with wealth, but there is some evidence suggesting that a non-linear (inverted $U$ shape) relationship between meat consumption and income has started to appear (Vranken et al. 2014). These issues illustrate some of the complexities of optimising dietary change to maximise health benefits, especially in low and middle income countries, where both under- and over-nutrition often co-exist, even in the same household (Popkin 2002).

It is well recognised that the production of different types of food have differential effects on the environment and hence dietary changes influence that impact. Modelling studies show that changes in future diets can have a significant impact on greenhouse gas (GHG) emissions from food production (Smith et al. 2013). The increased demand for dairy, meat and egg products in big cities in China has led to a rapid increase in landless, intensive livestock production systems with a negative impact on water quality (Liang et al. 2013). Animal manure from intensive animal farms are usually discharged to nearby waters, or dumped in lagoons, where the liquid fraction evaporates to air and drains to the subsoil with little beneficial use and with the release of nitrous oxide emissions (Wang et al. 2010, 2011). Also in China, the changes in food systems have increased phosphorus losses from agriculture to both the atmosphere and water systems as crop residues, animal manures and human waste are no longer incorporated into cropland (Ma et al. 2014). Excessive nutrient flows (e.g. nitrogen) cause water eutrophication with negative impacts on biodiversity, and exacerbate climate change through nitrous oxide emissions (Kahiluoto et al. 2014). Dietary changes may also have an impact on water systems as the volume of freshwater that is used to produce food varies according to the type of food produced (Hoekstra and Hung 2002).

In a globalized world economy, products derived from using the land are often not consumed where they are produced (Haberl et al. 2009; Grenz et al. 2007; Turner et al. 2007). Therefore, dietary changes occurring in one part of the world can also have an impact on the environment in other regions of the world. In Brazil the provision of substantial quantities of beef and soyabean meal to national and global markets has caused deforestation in the Brazilian Amazon (Pfaff and Walker 2010). Rapid economic growth in China and a diet richer in meat products has increased soyabean meal imports from Brazil to feed livestock produced in landless and intensive systems (Ma et al. 2014; Liang et al. 2013; Naylor et al. 2005). The correlation between specific planetary processes in one region of the world to distant and seemingly unconnected regions elsewhere has been defined as "teleconnections" (Steffen 2006).

The need to take environmental considerations into account, alongside dietary guidelines was pointed out by Gussow and Clancy (1986) in the 1980s, yet Lang (2005) noted that many nutritionists have not paid much attention to the impacts of nutrition patterns on the environment. Nonetheless, more recently, several studies relating these two issues have been published. For example, Macdiarmid (2013), investigated whether a healthy diet could also be an environmentally sustainable diet and highlighted the need to consider the impact of whole diets and not just individual components. Peters et al. (2009) investigated how the relation between the place where food is produced and the place where this food is consumed has an impact on the environment and the vulnerability of the food system. Tilman and Clark (2014) compiled and analysed global-level data to quantify relationships among diet, environmental sustainability and human health to evaluate potential future environmental impacts of the global dietary transition. Kahiluoto et al. (2014) investigated how much the food supply should be reduced if the planet is to be kept within safe nutrient boundaries and how much of this reduction would depend on population growth and on potential shifts in the agrifood systems.

The CGIAR, a global partnership that unites organizations engaged in research for a food secure future, ${ }^{1}$ adopted the goal of 'Improved Nutrition and Health', alongside a goal of 'Sustainable Management of Natural Resources' in its Strategy and Results Framework which was published in 2011 (CGIAR 2011). The focus to date has not brought these two goals together, but there will be increasing pressure to do so in the future. For example, the UN-led work to replace the Millennium Development Goals (which had a deadline of 2015) with new global targets to be called Sustainable Development Goals, ${ }^{2}$ currently (September 2014) includes 'sustainable agriculture' alongside the target on hunger, food security and nutrition: 'End hunger, achieve food security and improve nutrition and promote sustainable agriculture', bringing nutrition and environmental considerations into the same goal. This is in line with a more general trend in agricultural/ environmental research to adopt inter-disciplinary approaches. Recognition of the limitations of individual disciplines in resolving global challenges has grown over the last two to three decades resulting in a significant increase in collaboration

\footnotetext{
${ }^{1}$ http://www.cgiar.org/. The 'CGIAR' was originally the acronym for the 'Consultative Group on International Agricultural Research'. In 2008, CGIAR redefined itself as a global partnership. To reflect this transformation and yet retain its roots, 'CGIAR' was retained as a name. CGIAR is now a global research partnership for a food secure future.

${ }_{2} \mathrm{http}: / / w w w . s u s t a i n a b l e d e v e l o p m e n t 2015.0 r g /$
} 
between disciplines. Different disciplines view societal challenges from different perspectives and merging those perspectives can provide new insights.

This study, therefore, starts to explore how changes in diet (using food supply as the source of data) in countries which are already well down the path of 'nutrition transition' have had an impact on a range of environmental indicators, including GHG emissions, water use, nitrogen and phosphorus cycles and land use. Three case study countries were chosen: Brazil, China and India, as they have been undergoing rapid economic development for over a decade and together contribute over $30 \%$ of the world's population.

The objective of the analysis is to estimate environmental impacts of changes in the supply of food commodities in the three case study countries, as a first step in the process of identifying which environmental indicators might be considered a priority for measurement as the momentum of the nutrition transition increases in other developing countries.

The research questions addressed within this paper were, therefore:

1. What are recent trends in the supply of food components per capita in the 3 case study countries, separating out the impact of changes in diet from those of population growth?

2. What is the environmental impact of these major changes within the 3 countries?

3. What is the impact of trade of these changes on the likely location of environmental impact?

Conclusions are drawn about the need for taking environmental measurements beyond GHGs and the implications these might have for agricultural research aimed at addressing nutritional and environmental outcomes simultaneously.

\section{Methods}

\section{Food supply data}

FAOSTAT food balance data were used to present a picture of major changes in commodities contributing to a country's food supply in $\mathrm{kg}$ per capita per year and kcal per capita per day. The data are provided for 1961 and 2011 (the earliest and latest years of records available in the database). They reflect the total quantity of foodstuffs produced in a country added to the total quantity imported and adjusted to any change in stocks that may have occurred since the beginning of the reference period, minus the quantity exported, fed to animals or wasted in storage or transportation. Thus, the data give the supply of food stuffs available during that period (FAOSTAT 2015).

The FAO food supply data provide valuable information for tracking dietary changes both globally and at a national level. The data are based on food supply as defined by FAO, above, which is often used as a proxy for consumption. It should not, however, be interpreted as absolute consumption because it describes the availability of food in a country but does not account for food waste in the retail chain or home. Per capita supply of each food item takes into account the population estimates for the respective country and is available in terms of nutrients (protein, energy and fat). In this study we have used food supply data in terms of dietary energy value (kcal.capita ${ }^{-1}$.day $^{-1}$ ) as an indicator of changes in diet in China, Brazil and India, as distinct from the increases associated with population growth.

The plant items investigated were cereals, fruits, oil crops, pulses, starchy roots, sugar and sweeteners, vegetable oils, and vegetables. Animal products were bovine meat, poultry meat, pig meat and milk. Data for Europe were included as a benchmark of a developed country.

\section{Trade data}

The data on value (US\$) of world food exports were taken from the World Trade Organisation's statistics database ${ }^{3}$ and the value of processed food traded from USDA. ${ }^{4}$ The data on quantity (metric tons) of individual commodities traded in 2013/14 were also taken from USDA $^{5}$ which provides a summary of the main importing and exporting countries, while the changes in imports from 1961 to 2011 were taken from FAOSTAT.

\section{Environmental impacts calculations}

In this study we used part of the planetary boundaries framework, adapted from Rockström et al. (2009), to estimate the environmental impacts in the three case study countries due to nutrition transitions. The planetary boundaries framework defines the safe operating space for humanity with respect to the Earth system and its biophysical subsystems (or processes), namely climate change, biodiversity loss, nitrogen $(\mathrm{N})$ and phosphorus (P) cycles, stratospheric ozone depletion, ocean acidification, global freshwater use, land use, atmospheric aerosol loading, and chemical pollution. Data available allowed the calculation of the impact of nutrition transition on freshwater use, $\mathrm{N}$ and $\mathrm{P}$ cycles, land requirements and GHG emissions. These were estimated for the main food commodities which are recognised as important in the nutrition transition, namely cereals, fruits, oil crops, sugar crops, vegetables, milk, poultry meat, pig meat and bovine meat. All the impacts were estimated per kcal of food type.

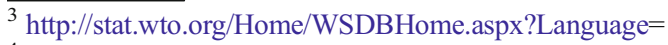

${ }^{4} \mathrm{http}$ ://www.fas.usda.gov/data/us-processed-food-exports-growthoutlook

${ }^{5}$ http://apps.fas.usda.gov/psdonline/ (all accessed on 16 and 29 August 2014)
} 


\section{Global freshwater use}

The water footprint of some selected food products from vegetable and animal origin per unit of energy (litres per kcal) is provided by the UNESCO 2010 report (Mekonnen and Hoekstra 2010). This study gives the total water footprint per ton $\left(\mathrm{m}^{3} /\right.$ ton), which is the sum of green, blue and grey water footprints, per food type (e.g. vegetables, fruits, sugar crops, cereals), without disaggregating for specific foods. The blue water footprint refers to the volume of surface and groundwater consumed (evaporated) as a result of the production of a good; the green water footprint refers to the rainwater consumed. The grey water footprint of a product refers to the volume of freshwater that is required to assimilate the load of pollutants based on existing ambient water quality standards (Hoekstra and Chapagain 2007). The water footprint by product type was then multiplied by the food supply of each of these products in kcal per capita per day.

\section{Nitrogen and phosphorus cycles}

The International Fertilizer Industry Association ${ }^{2}$ provides activity data on mineral fertiliser application $(\mathrm{N})$ and phosphate $\left(\mathrm{P}_{2} \mathrm{O}_{5}\right)$ use in thousands of tonnes ( 000 tonnes) per crop (soybean, cereals, fruits, oil crops, sugar crops and vegetables) for China, India and Brazil, for the period 2006-2011. The total N and $\mathrm{P}_{2} \mathrm{O}_{5}$ quantities used per crop (soybean meal, cereals, fruits, oil crops, sugar crops and vegetables) in $\mathrm{kg}$ was divided by the crop production (soybean meal, cereals, fruits, oil crops, sugar crops and vegetables) produced in China, India and Brazil, and then divided by the amount (kcal per $\mathrm{kg}$ ) of product to obtain the quantity of $\mathrm{N}$ and $\mathrm{P}$ applied per kcal of food type. This was finally multiplied by the food supply of each of these products in kcal per capita per day.

\section{Greenhouse gas emissions (GHG)}

GHG emissions were estimated in terms of $\mathrm{kg}$ of $\mathrm{CO}_{2}$ equivalent per capita per day for China, India and Brazil. For crop products (cereals, fruits, oil crops, sugar crops and vegetables), total GHG emissions in $\mathrm{kg} \mathrm{CO}$ eq were the sum of GHG emissions from crop residues and GHG emissions due to mineral $(\mathrm{N})$ fertiliser application. Greenhouse gas emissions per crop product $\left(\mathrm{kg} \mathrm{CO}_{2} \mathrm{eq}\right)$ were then divided by the amount of kcal per $\mathrm{kg}$ of crop type (cereals, fruits, oil crops, sugar crops and vegetables) to obtain $\mathrm{kg} \mathrm{CO}_{2}$ eq per kcal of product. These values were then multiplied by the food supply in kcal per capita per day.

The FAOSTAT Emissions Agriculture database provides data for GHG emissions from crop residues for wheat and maize in China, India and Brazil. These emissions are estimated using Tier 1 methods, following the 2006 Intergovernmental Panel on Climate Change (IPCC) Guidelines for National
Greenhouse Gas Inventories (IPCC 2006). Greenhouse gas emissions due to mineral $(\mathrm{N})$ fertiliser application were estimated by using the multivariate empirical model of Stehfest and Bouwman (2006). The fertiliser-induced emissions model of Stehfest and Bouwman (2006) is a Tier 2 model.

Regarding livestock, the FAOSTAT Emissions Agriculture database provides country-level estimates of greenhouse gas (GHG) emissions (in $\mathrm{kg} \mathrm{CO}_{2}$ eq) from enteric fermentation and manure management for dairy and non-dairy cattle, swine and poultry. Total (enteric fermentation + manure management) GHG emissions in $\mathrm{kg} \mathrm{CO}_{2}$ eq were divided by the quantity of livestock product in $\mathrm{kg}$ (bovine, pig and poultry meat, $\mathrm{kg}$ of milk) and divided by the quantity of kcal per $\mathrm{kg}$ of product to obtain GHG emissions in $\mathrm{kg} \mathrm{CO}_{2}$ eq per kcal of livestock product. This was then multiplied by the food supply of each of these products in kcal per capita per day.

\section{Land requirements}

The amount of land in hectares needed to produce $1 \mathrm{kcal}$ of product (e.g. sugar crops, vegetables, fruits, wheat, maize, oil crops) in China, India and Brazil, was estimated by dividing yield data (in $\mathrm{kg} / \mathrm{ha}$ ) provided by FAOSTAT database by the amount of kcal per $\mathrm{kg}$ of crop type. This was then multiplied by the food supply of each of these products in kcal per capita per day.

\section{Results}

\section{Trends in nutrition transition}

Data on the per-capita supply of the products identified as showing the most consistent increases in the three case study countries are given in Table 1 for 1961 and 2011. Data for Europe are included as a benchmark of a developed region, to illustrate both the difference in availability, and the degree of change over the 51 year period compared to the three case study countries. Data for kcal are included to facilitate isocaloric comparisons between commodities.

All three case study countries and Europe showed considerable increases in the supply of vegetable oil, while the difference in supply of other commodities was more variable between case study countries, in particular for meat supply. In Brazil, per-capita meat supply increased to a higher level than for Europe by 2011, largely due to increases in bovine and poultry meat. The data for China indicate a higher percapita supply of meat, mainly due to an increase in pig meat. The increase in meat supply in India, however, is very small, which would be expected as the majority of the population in India is vegetarian. By 2011, fruit supply in Brazil and vegetable supply in China were higher than in Europe. In India, the supply of fruit and vegetables was not so divergent and both 


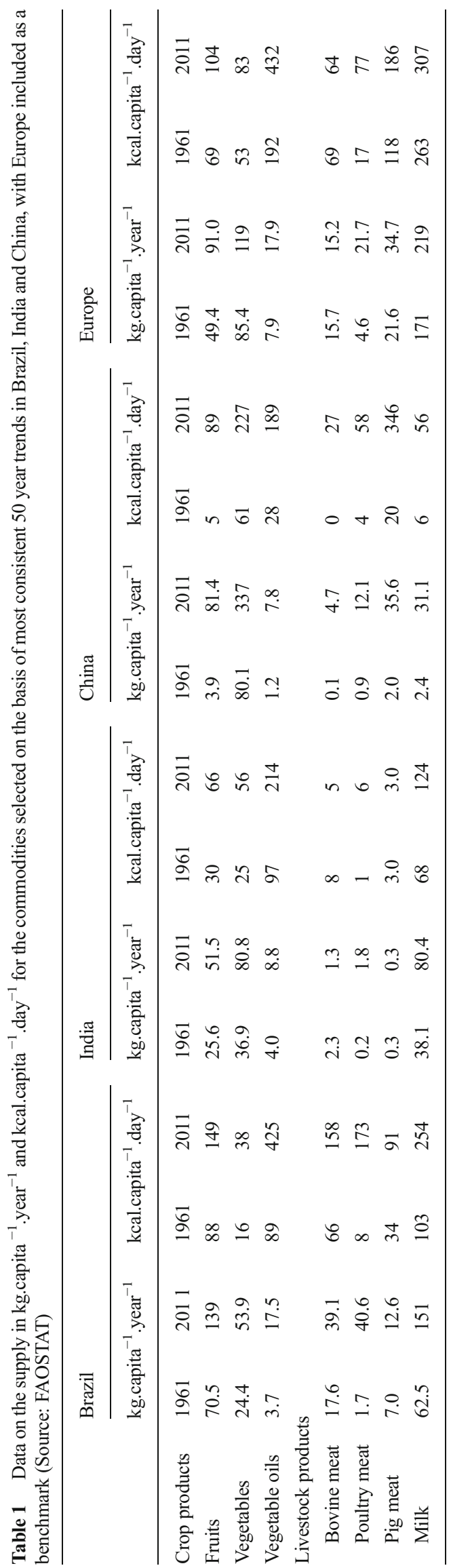

were lower than European levels. In comparison, the supply of milk in Brazil, China and India on a per capita basis have increased by similar amounts over the past five decades, but remain lower than Europe.

To illustrate that these changes in commodity supply have been changing over a long period, but not consistently, graphs for supply of meat, fruits and vegetables are shown in Fig. 1a, b, c.

These graphs show the temporal differences in the nutrition transition in the three countries, with meat supply not increasing until the late 1980s in Brazil and China, while vegetable oil started to increase in the 1970s in Brazil and China. The trend in fruit and vegetable supply shows a dramatic increase since the early 1990s in China, not observed in the other countries.

The estimation of environmental impacts depends on production systems which change over time. In an attempt to minimise the impact of longer term changes in production systems, a period of 11 years (2001-2011) was chosen for analysis of the environmental impact of the nutrition transition, as changes in supply will be apparent, whilst the influence of longer term changes in production systems will be minimised.

The increase in per-capita supply over the 11 years from 2001 to 2011 is given in Table 2, along with its conversion based on the population in each country in 2011. These give the increase in each food commodity which was due to dietary change rather than population increase, but they also highlight the impact of the much higher populations in China and India than Brazil, when looking at national environmental impact as shown in Fig. 2.

\section{Environmental impacts}

Analysis of food supply data identified the food groups for which supply (kcal/capita) has changed significantly over the last 10 years, at a global level. The following section on trade identifies significant trade in some of these food groups. In this section, the emphasis is on defining the key environmental impacts associated with these food groups and quantifying which are being most influenced by changing diets.

The estimated impact on water, N, P, land and GHG of the nutrition transition is expressed as global average impact per kcal available by individual food products. The impacts for individual products are summarised in Table 3.

The impacts of nutrition transition on the environment were measured through six indicators, namely, water footprint, land area, mineral $\mathrm{N}$ use, phosphate use and GHG emissions.

Figure 2a shows that the changes associated with the nutrition transition that had the highest water requirements (in litres) per capita per day were for bovine meat in Brazil (this includes water use associated with soybean production), pig meat in China and cereals in China and India. Figure 2b shows that land area required per capita per day regarding the increase in vegetable oil supply associated with the nutrition 
Fig. 1 Trends in food supply of food products: a meat; $\mathbf{b}$ vegetable oils; $\mathbf{c}$ fruits and vegetables ( $\mathrm{kg}$ per capita per year) in Brazil, China, India and Europe over 50 years (Source FAOSTAT) a Trend in meat supply in kg.capita ${ }^{1} \cdot \mathrm{yr}^{-1}$

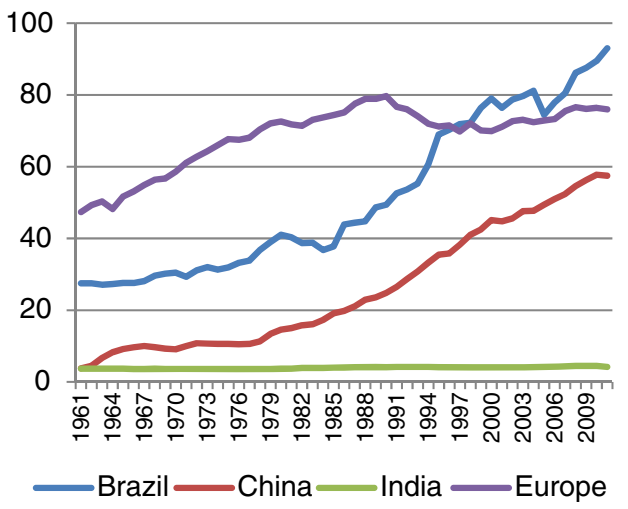

b Trend in vegetable oils supply in kg.capita ${ }^{-1} \cdot \mathrm{yr}^{-1}$

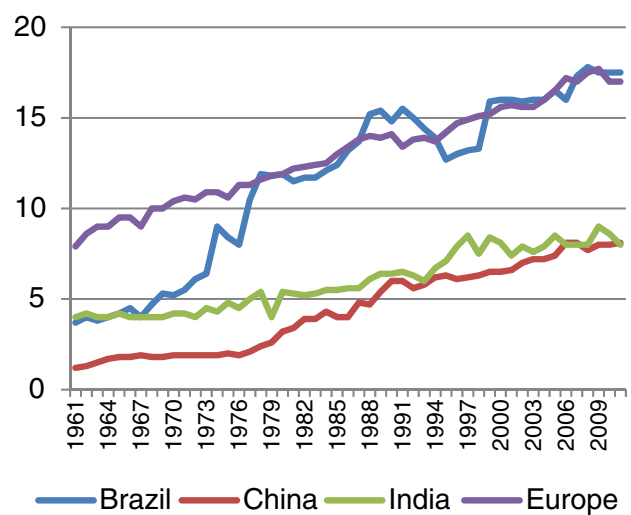

C Trend in fruits and vegetables supply in kg.capita ${ }^{-1} \cdot \mathrm{yr}^{-1}$

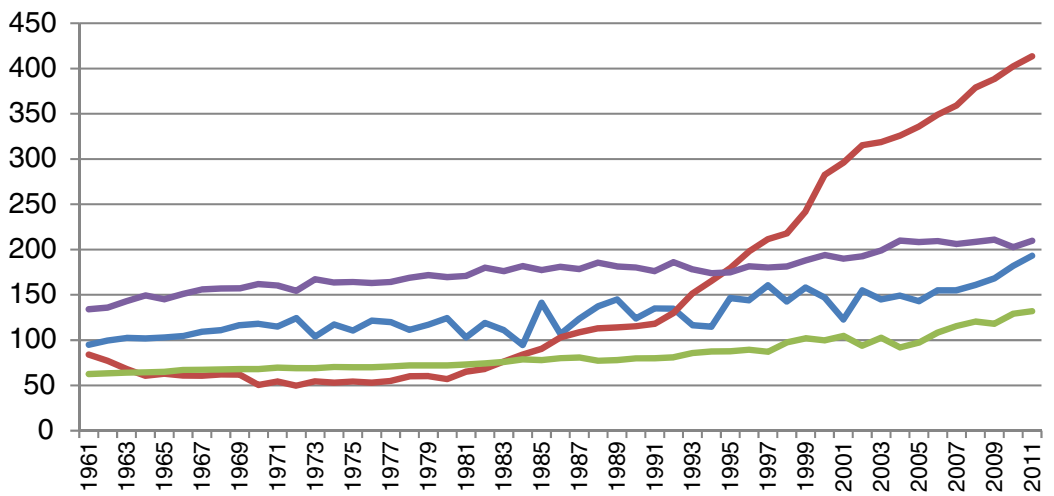

Brazil China India Europe

transition is highest for India and Brazil. In India, the area required per capita per day for increased cereal supply is also considerable. Figure 2 and d show that from the food types analysed, cereals have higher requirements of nitrogen $(\mathrm{N})$ and phosphorus (P) in kg.capita ${ }^{-1}$.day $^{-1}$, respectively. Figure 2e shows that greenhouse gas emissions are highest per capita per day for the nutrition transition associated with bovine meat and milk in Brazil and cereals in India.

These results reveal that the consumption of resources (water, P, N, land) and GHG emissions associated with the production of each food type analysed depend on the geographical area where these are grown. However, the environmental impacts caused by the consumption of those resourses are global, especially in relation to GHG emissions. Trading patterns in these commodities are considered in the next section as an aid to the discussion on environmental impacts.

\section{The links between nutrition trends and trade}

At a global level, food exports have more than doubled in value over the last 10 years (WTO Statistics database), which is linked not just to the volume of trade but also the increasing potential for added value from processing. The value of exports of processed food increased on a similar trajectory, from US \$ 150 billion (27\% of world food exports) in 2003 to 400 billion (29\%) in 2012. ${ }^{6}$ Based on the WTO statistics database, world food exports were $83.5 \%$ of total agricultural exports in 2013. This increase in trade in processed products makes comparisons of time trajectories of individual commodities difficult, so only recent data are given here.

This increase in trade in processed foods is apparent in the FAO trade statistics on China, which reported very substantial increases in the import of fresh fruit from 155 thousand tonnes in 2001 to 738 thousand tonnes in 2011, matched by an increase in the export of prepared fruit from 384 thousand tonnes to 1207 thousand tonnes. The import of boneless beef and veal increased from 2001 to 2011 from $<4000$ to $\sim 18,000$ tonnes (FAOSTAT) while the imports of chicken meat and vegetable oil were quite variable over the same 10 year period, without any substantial increase. With respect to the commodities showing significant increases in Tables 1 and 2, none of the increases for Brazil appeared to be due to increases in imports. One trade figure which is worth noting for Brazil,

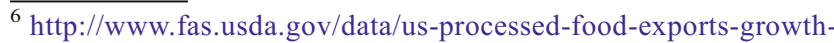
outlook
} 
Table 2 Increase in supply of total kcals per person (per food group) in the 3 case study countries between 2001 and 2011 which was associated with the nutrition transition as distinct from population increase

\begin{tabular}{|c|c|c|c|c|c|c|}
\hline \multirow[b]{2}{*}{ Food crops } & \multicolumn{3}{|c|}{$\begin{array}{l}\text { Average increase between } 2001 \\
\text { and } 2011\left(\text { kcal.capita }^{-1} \text {.day }{ }^{-1}\right)\end{array}$} & \multicolumn{3}{|c|}{$\begin{array}{l}\text { Increase in national supply between } 2001 \text { and } 2011 \\
\left.\text { due to nutrition transition (million kcals day }{ }^{-1}\right)^{\mathrm{a}}\end{array}$} \\
\hline & Brazil & China & India & Brazil & China & India \\
\hline Cereals & 955 & 1440 & 1394 & 188 & 2015 & 1702 \\
\hline Fruits & 149 & 90 & 66 & 29 & 126 & 81 \\
\hline Oil crops & 425 & 195 & 214 & 84 & 273 & 261 \\
\hline Sugar crops & 13 & 0 & 8 & 3 & 0 & 10 \\
\hline Vegetables & 38 & 224 & 56 & 7 & 313 & 68 \\
\hline \multicolumn{7}{|l|}{ Livestock } \\
\hline Milk & 254 & 57 & 124 & 50 & 80 & 151 \\
\hline Poultry meat & 173 & 61 & 6 & 34 & 85 & 7 \\
\hline Bovine meat & 158 & 27 & 5 & 31 & 38 & 6 \\
\hline Pig meat & 91 & 345 & 3 & 18 & 483 & 4 \\
\hline
\end{tabular}

${ }^{\text {a }}$ Average increase multiplied by population in 2011 (total kcal.day ${ }^{-1}$ ) however, is the increase in export of soyabean cake/meal which is the main provider of protein in livestock diets. According to FAOSTAT database export of soyabean cake increased from 11 million tonnes in 2001 to 14 million tonnes in 2011, and other sources show this has continued to increase. For India, imports of both vegetable oils and milk equivalents (sum of all products containing milk) increased over the decade from 2001 to 2011, from 2 to 19 thousand tonnes for vegetable oils and from 37 thousand to 367 thousand tonnes for milk equivalents. The import of vegetables into India was very low. USDA data on trade was used to identify the major exporting and importing countries for these commodities, as shown in Table 4.

Indonesia and Malaysia are the major exporters of vegetable oils and Argentina and Brazil the major exporters of protein meals. Trade in livestock products (on a weight basis) was significantly lower than that for protein meals in 2013/14, 10 million metric tons for broiler meat and beef and $<2$ million metric tons in whole milk powder in 2013/14 (USDA).

Data on the quantity of trade in fruit and vegetables at a global level is more difficult to find, but this category now constitutes the largest part of developing country exports, with significant exports to industrial countries, whereas developing country trade in other crops tends to be inter-regional (Ataman and $\mathrm{Ng} 2013$ ).

\section{Discussion}

\section{The meaning of trends in food supply in relation to environmental impacts}

The data presented on per-capita food supply illustrate major changes in types of crops produced and in total animal production in recent decades in the three case study countries, as a result of changes which are not associated simply with population growth. The data presented show increases in vegetable oils in all three case study countries and increases in livestock products (though only milk, not meat in India).

The results on environmental impacts illustrate the impacts of relative changes in the supply of different foods on a range of environmental indicators. There is an extensive literature on the impacts of livestock on the environment (e.g. Ripple et al. 2014; Bajželj et al. 2014) and hence only the impact of increased supply of livestock products on water and greenhouse gas emissions were estimated. The trade figures on the export of soybean meal indicate that the impact of increases of livestock production in other countries will impact disproportionately on Brazil. As expected, bovine meat shows the largest environmental 'footprint' for both of these indicators in Brazil, where the increase in supply was high. In China, the impact of the increase in pig meat was equal to that of cereals on water use. These figures are consistent with other estimates of the environmental impact of livestock production (Ripple et al. 2014).

The major impact of the increase in supply of vegetable oils is on land use, but the trade figures highlight the significant imports of vegetable oils to both China and India from Indondesia and Malaysia. This highlights that the impact of dietary changes in one country may have environmental impacts in another.

In terms of fertiliser use, cereals in both India and China dominate, followed by the increase in vegetables in India. Fruits have a relatively low environmental footprint for all indicators, despite significant increases in their contribution to food energy supply.

\section{What does this mean for agricultural research targeted at contributing to nutrition and health outcomes?}

The environmental impacts of food production can no longer be considered as simply local as GHG emissions have a global 
Fig. 2 Impacts on the environment of food products related to the nutrition transition per capita and per day: a Water footprint; b GHG emissions; c Mineral nitrogen (N) use; $\mathbf{d}$ Phosphorus (P) use; e GHG emissions

\section{a Water footprint}

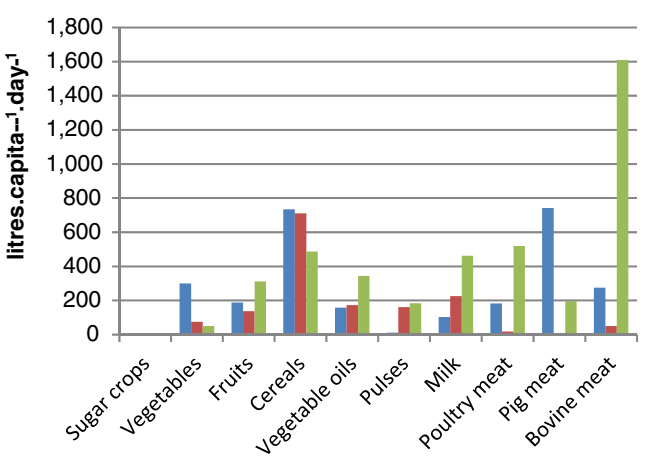

China $=$ India Brazil

c Nitrogen $(\mathrm{N})$ use

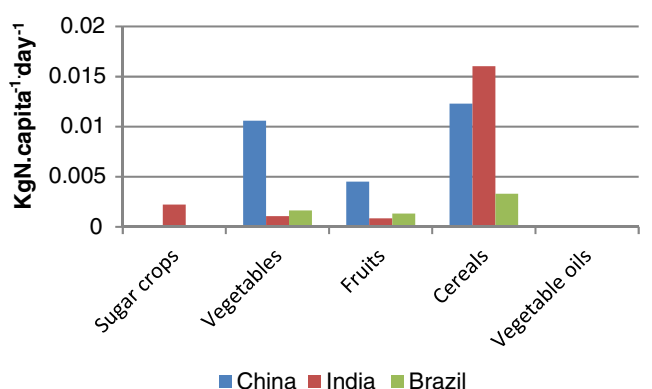

b Land area

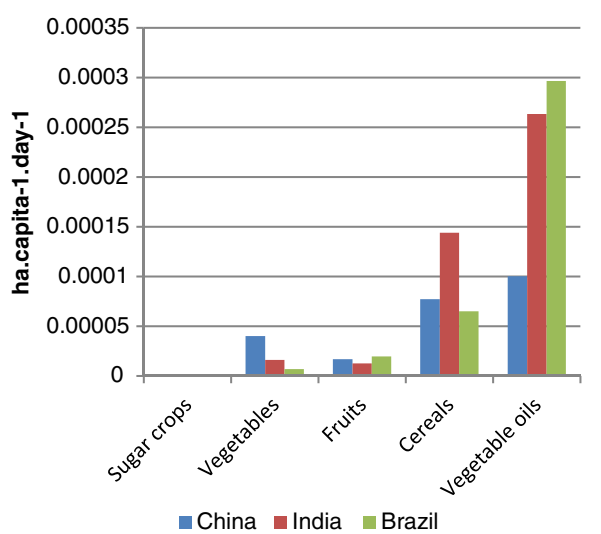

d Phosphorus $(\mathrm{P})$ use

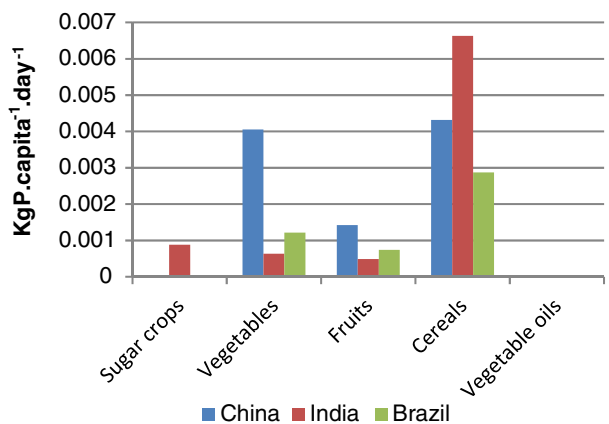

e GHG emissions

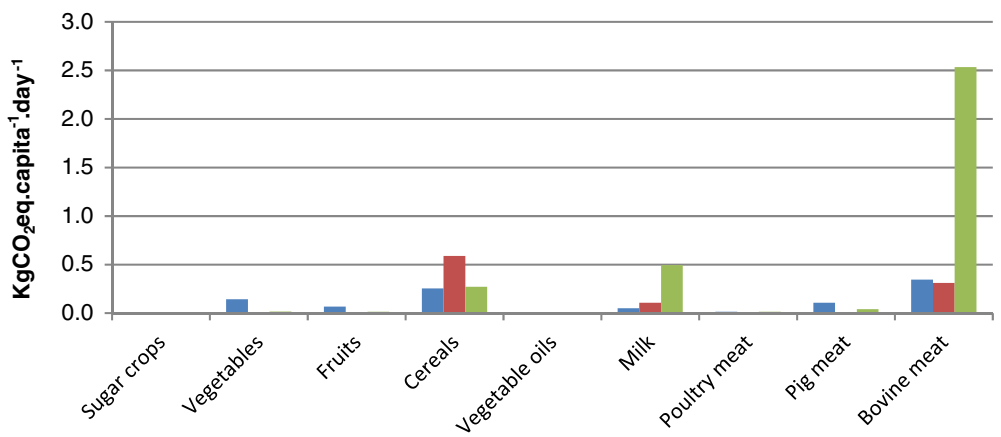

- China $n$ India $n$ Brazil

impact, which in turn impacts on food production. Trade in key products such as vegetable oils and soybean means that the impact is not experienced in the country of consumption (Table 4).

The analysis in this paper has sought to distinguish between the environmental impacts associated with increasing population and the impacts associated with presumed changes in diet, using FAO food supply data as a surrogate source of information, and three countries which have undergone recent increases in economic growth as case studies.

The results have shown that in Brazil and China, supply of fruit and vegetables (respectively) already meet recommended minimum intakes. These country-specific findings agree with those recently published by Siegel et al. (2014), who also highlighted the high demand:supply ratios for many low income countries but also for some lower- and upper-middle income countries. Siegel et al. (2014) concluded that there is at least a $22 \%$ supply gap in relation to meeting current health needs, but our analysis goes on to suggest that indicators such as fertiliser use need to be measured when recommending increases in the contribution of vegetables to diets, while recognising that there will be big differences between different types of vegetable. There is much less public investment in horticultural research compared to research on staple crops 
Table 3 Input requirements and GHG emissions per kcal produced

\begin{tabular}{|c|c|c|c|c|c|c|c|}
\hline Food & Country & $\begin{array}{l}\text { Energy content } \\
\mathrm{kcal} / \mathrm{kg}\end{array}$ & $\begin{array}{l}\text { Water footprint } \\
\text { liters/kcal }\end{array}$ & $\begin{array}{l}\mathrm{N} \text { applied } \\
\mathrm{g} \mathrm{N} / \text { kcal }\end{array}$ & $\begin{array}{l}\text { P applied } \\
\text { g P/kcal }\end{array}$ & $\begin{array}{l}\text { Land area } \\
10^{\wedge} 6 \mathrm{ha} / \mathrm{kcal}\end{array}$ & $\begin{array}{l}\text { GHG emissions } \\
\mathrm{g} \mathrm{CO}_{2} \text { eq/kcal }\end{array}$ \\
\hline \multirow[t]{3}{*}{ Sugar crops } & China & 285 & 0.69 & 0.014 & 0.0051 & 0.0510 & 0.174 \\
\hline & India & & & 0.278 & 0.1105 & 0.0495 & 0.084 \\
\hline & Brazil & & & 0.003 & 0.0011 & 0.0472 & 0.029 \\
\hline \multirow[t]{3}{*}{ Vegetables } & China & 240 & 1.34 & 0.047 & 0.0181 & 0.1785 & 0.635 \\
\hline & India & & & 0.019 & 0.0114 & 0.2866 & 0.193 \\
\hline & Brazil & & & 0.043 & 0.0320 & 0.1799 & 0.430 \\
\hline \multirow[t]{3}{*}{ Fruits } & China & 460 & 2.09 & 0.050 & 0.0158 & 0.1863 & 0.748 \\
\hline & India & & & 0.013 & 0.0074 & 0.1923 & 0.128 \\
\hline & Brazil & & & 0.009 & 0.0050 & 0.1318 & 0.088 \\
\hline \multirow[t]{3}{*}{ Cereals } & China & 3208 & 0.51 & 0.009 & 0.0030 & 0.0535 & 0.177 \\
\hline & India & & & 0.012 & 0.0048 & 0.1032 & 0.422 \\
\hline & Brazil & & & 0.003 & 0.0030 & 0.0680 & 0.285 \\
\hline \multirow[t]{3}{*}{ Vegetable oils } & China & 2908 & 0.81 & 0.00014 & 0.000039 & 0.5137 & 0.0154 \\
\hline & India & & & 0 & 0 & 1.2302 & 0.0344 \\
\hline & Brazil & & & 0.0002 & 0.000077 & 0.6978 & 0.0119 \\
\hline \multirow[t]{3}{*}{ Soybeans } & China & 4460 & 0.481 & 0.06 & 0.057617 & 0.2349 & 0.7451 \\
\hline & India & & & 0.01 & 0.010188 & 0.3357 & 0.0853 \\
\hline & Brazil & & & 0.0112 & 0.011200 & 0.1722 & 0.1101 \\
\hline \multirow[t]{3}{*}{ Milk } & China & 560 & 1.82 & $\mathrm{~N} / \mathrm{A}$ & $\mathrm{N} / \mathrm{A}$ & $\mathrm{N} / \mathrm{A}$ & 0.884 \\
\hline & India & & & & & & 0.857 \\
\hline & Brazil & & & & & & 1.948 \\
\hline \multirow[t]{3}{*}{ Poultry meat } & China & 1440 & 3 & N/A & N/A & N/A & 0.221 \\
\hline & India & & & & & & 0.321 \\
\hline & Brazil & & & & & & 0.083 \\
\hline \multirow[t]{3}{*}{ Pig meat } & China & 2786 & 2.15 & N/A & N/A & N/A & 0.307 \\
\hline & India & & & & & & 1.470 \\
\hline & Brazil & & & & & & 0.450 \\
\hline \multirow[t]{3}{*}{ Bovine meat } & China & 1513 & 10.19 & N/A & N/A & N/A & 12.78 \\
\hline & India & & & & & & 62.16 \\
\hline & Brazil & & & & & & 16.04 \\
\hline
\end{tabular}

(see e.g. Pingali 2015) and in many countries agricultural policies have also been implicated in maintaining higher prices for healthier foods. For example, Birt (2007) drew an interesting comparison between $\mathrm{WHO} / \mathrm{FAO}$ proportional targets for
Table 4 Largest trade quantities in thousands of metric tons (USDA: http://apps.fas.usda.gov/ psdonline/)

\begin{tabular}{llll}
\hline Commodity & $\begin{array}{l}\text { Global exports in 2013/14 } \\
(1000 \text { metric tons })\end{array}$ & $\begin{array}{l}\text { Countries with biggest } \\
\text { share of exports }\end{array}$ & $\begin{array}{l}\text { Countries with biggest } \\
\text { share of imports }\end{array}$ \\
\hline $\begin{array}{l}\text { Crops and products } \\
\text { Major vegetable oils }\end{array}$ & 68,520 & Indonesia, Malaysia & India, China \\
$\begin{array}{l}\text { Livestock-related } \\
\text { Protein meals }\end{array}$ & 61,449 & Argentina \& Brazil & EU \\
$\begin{array}{l}\text { Broiler meat } \\
\text { Beef }\end{array}$ & $10,207^{\text {a }}$ & Brazil, USA & Japan, Saudi Arabia \\
Whole milk powder & 19451 & Brazil, India \& Australia & Russia \\
Non-fat dry milk & 1747 & New Zealand & China \\
\hline
\end{tabular}

${ }^{a}$ Some countries excluded in the dataset 
consumption of fruits and vegetables versus European Union proportional expenditure in the Common Agricultural Policy budget on fruit and vegetables. The latter was a much smaller fraction, compared to expenditure on meat, dairy and animal food which, in contrast, was a higher proportion than the WHO/FAO (2002) recommended levels. He drew the conclusion that 'By heavily subsidising milk and beef, they ensure that foods with high saturated fat content are more affordable for people on low incomes. By contrast, fruit and vegetables, which receive little support from $C A P$, are relatively expensive'. Research budgets linked to economic drivers tend to have followed a similar bias, whereas allocating funds to achieve nutritional and/or environmental goals could provide a different emphasis.

Fruits and vegetables are a very heterogeneous food group, however, stimulating production of specific fruits or vegetables could have a range of influences on environmental impact. This heterogeneity also extends to their nutrient content (e.g. Burlingame et al. 2009) and hence decision-makers need to have evidence on both nutritional value and environmental impact. Others (e.g. Weinberger and Lumpkin 2007) have already called for development agencies to invest more in horticultural research, although their emphasis was more on identifying new technologies to improve productivity. We would endorse this call, but recommend a simultaneous focus on nutritional quality and maximising water and nutrient use efficiency.

Globally, public research funds have focused more on staple crops rather than on the wider diversity of crops needed for a nutritionally appropriate diet, and as a result there is limited evidence on sutainable production of fruits and vegetables with a high nutritional content. Given the increasing interest of international organisations such as the FAO and WHO in promoting nutritional diets, a rebalancing of public funding towards increasing the diversity of crops should be a key part of an implementation strategy. Bringing these disciplines together to consider future food production in terms of nutrition security not just food security, should be a priority.

Another factor which needs to be considered in identifying future priorities is the potential impact of climate change on the productivity of different crops. Rockström et al. (2009) consider that climate change has already transgressed the boundaries of a safe operating space for humanity with respect to the Earth system. The food commodities identified as of particular interest in this paper are at different levels of risk from future climate change.

Empirical evidence suggests that increases in temperature in the period 1980-2008 have already resulted in average global maize and wheat yield reductions of 3.8 and $5.5 \%$ respectively, compared to a non-climate change scenario (Lobell et al. 2011). Challinor et al. (2007) assessed several studies and concluded that whilst the magnitude of the response of crop yield to climate change varies considerably, the sign of the change is mostly negative.
While soybean meal, fruits, oil crops and vegetables may be threatened by increased temperatures, and subject to increased losses through more frequent and severe climatic extremes (Reichstein et al. 2013), changes in precipitation might pose the greatest threat. Table 3 shows the highest water footprints for livestock production, followed by fruits and then vegetables; therefore the production of these commodities might be at risk.

\section{Conclusions}

The nutritional and health consequences of the dietary transition in middle and low income countries have been recognised for some time, but the environmental consequences of these dietary changes are less well studied. It is essential that not only nutrition and health are considered in future national and international policy development in terms of the consequences of the nutrition transition, but also the environmental impact. Research strategies designed to co-deliver economic, environmental and health goals will need to draw on inter-disciplinary collaborations to define priority research questions. They should include a range of environmental indicators and not just greenhouse gas emissions and they need to take into account differences in impacts (partly due to different production systems) between countries.

Conflict of interest The authors have no conflict of interest to declare.

Open Access This article is distributed under the terms of the Creative Commons Attribution License which permits any use, distribution, and reproduction in any medium, provided the original author(s) and the source are credited.

\section{References}

Ataman, A. M., \& Ng, F. (2013). The Evolution of Agricultural Trade Flows, Discussion Paper, Turkish Economic Association, No. 2013/2.

Bajželj, B., Richards, K. S., Allwood, J. M., Smith, P., Dennis, J. S., Curmi, E., \& Gilligan, C. A. (2014). The importance of food demand management for climate mitigation. Nature Climate Change, 4, 924-929.

Birt, C. (2007). A CAP on health? The impact of the EU Common Agricultural Policy on Public Health. London: The Faculty of Public Health.

Burlingame, B., Charrondier, R., \& Mouille, B. (2009). Food composition is fundamental to the cross-cutting initiative on biodiversity for food and nutrition. Journal of Food Composition and Analysis, 22, 361-365.

Challinor, A. J., Wheeler, T. R., Garforth, C., Craufurd, P., \& Kassam, A. (2007). Assessing the vulnerability of food crop systems in Africa to climate change. Climatic Change, 83, 381-399.

CGIAR. (2011). A strategy and framework results for the CGIAR. For submission to the CGIAR Funders Forum February 20, 2011. http:// 
www.cgiarfund.org/sites/cgiarfund.org/files/Documents/PDF/srf_ feb20 2011.pdf. Accessed 09 Oct 2014)

FAOSTAT. (2015). FAO food balance data: http://faostat3.fao.org/ faostat-gateway/go/to/browse/FB/FBS/E. Accessed 26 March 2015.

Grenz, J., Vetouli, T., Tzitzikli, E., \& Sauerbom, J. (2007). Umweltwirkungen der globalen Sojawirtschaft. GAIA, 16(3), 208214.

Gussow, J. D., \& Clancy, K. (1986). Dietary guidelines for sustainability. Journal of Nutrition Education and Behavior, 18(1), 1-4.

Haberl, H., Erb, K.-H., Krausmann, F., Berecz, S., Ludwiczek, J. N., Martínez-Alier, A. M., \& Schaffartzik, A. (2009). Using embodied HANPP to analyze teleconnections in the global land system: conceptual considerations, Geografisk Tidsskrift. Danish Journal of Geography, 109(2), 119-130.

Hoekstra, A. Y., \& Hung, P. Q. (2002). Virtual water trade: A quantification of virtual water flows between nations in relation to international crop trade. Value of Water Research Report Series No. 11, UNESCO-IHE, Delft, The Netherlands, 2002. http://www. waterfootprint.org/Reports/Report11.pdf. Accessed 12 June 2014.

Hoekstra, A. Y., \& Chapagain, A. K. (2007). Water footprints of nations: water use by people as a function of their consumption pattern. Water Resources Management, 21(1), 35-48.

IPCC. (2006). IPCC Guidelines for National Greenhouse Gas Inventories. Eggleston, H. S., Buendia, L., Miwa, K., Ngara, T., \& Tanabe, T. (eds). Institute for Global Environmental Strategies. Volume 4 Agriculture, Forestry and Other Land Use. Available at: http://www.ipcc-nggip.iges.or.jp/public/2006gl/vol4.html.

Kahiluoto, H., Kuisma, M., Kuokkanen, A., Mikkila, M., \& Linnanen, L. (2014). Taking planetary nutrient boundaries seriously: Can we feed the people? Global Food Security, 3(1), 16-21.

Lang, T. (2005). Food control or food democracy? Re-engaging nutrition with society and the environment. Public Health Nutrition, 8(6A), 730-737.

Liang, L., Lal, R., Du, Z., Wu, W., \& Meng, F. (2013). Estimation of nitrous oxide and methane emission from livestock of urban agriculture in Beijing. Agriculture, Ecosystems and Environment, 170, $28-35$.

Lobell, D. B., Schlenker, W., \& Costa-Roberts, J. (2011). Climate trends and global crop production since 1980. Science, 333, 208-218.

Ma, L., Guo, J., Velthof, G., Li, Y., Chen, Q., Mab, W., Oenema, O., \& Zhang, F. (2014). Impacts of urban expansion on nitrogen and phosphorus flows in the food system of Beijing from 1978 to 2008. Global Environmental Change, 28, 192-204.

Macdiarmid, J. I. (2013). Is a Healthy Diet an environmentally sustainable diet? Proceedings of the Nutrition Society, 72, 13-20.

Mekonnen, M.M., \& Hoekstra, A.Y. (2010). The green, blue and grey water footprint of farm animals and animal products, Value of Water Research Report Series No. 48, UNESCO-IHE, Delft, the Netherlands.

Naylor, R., Steinfeld, H., Falcon, W., Galloway, J., Smil, V., Bradford, E., Alder, J., \& Mooney, H. (2005). Losing the links between livestock and land. Science, 310, 1621-1622.

Ng, M., Fleming, T., Robinson, M., Thomson, B., Graetz, N., Margono, C., et al. (2014). Global, regional, and national prevalence of overweight and obesity in children and adults during 1980-2013: a systematic analysis for the Global Burden of Disease Study 2013. Lancet, 384, 766-781.

Peters, C. J., Bills, N. L., Wilkins, J. L., \& Fick, G. W. (2009). Foodshed analysis and its relevance to sustainability. Renewable Agriculture and Food Systems, 24(1), 1-7.

Pfaff, A., \& Walker, R. (2010). Regional interdependence and forest 'transitions': substitute deforestation limits the relevance of local reversals. Land Use Policy, 27, 119-129.

Pingali, P. (2015). Agricultural Policy and Nutrition Outcomes - getting beyond the preoccupation with staple grains. Food Security This issue.
Popkin, B. M. (2002). Part II. What is unique about the experience in lower- and middle income less-industrialised countries compared with the very-high income industrialised countries? The shift in stages of the nutrition transition in the developing world differs from past experiences! Public Health Nutrition, 5(1A), 205-214.

Popkin, B. M. (2003). The nutrition transition in the developing. World Development Policy Review, 21(5-6), 581-597.

Reichstein, M., Bahn, M., Ciais, P., Frank, D., Mahecha, M., Seneviratne, S., Zscheischler, J., Beer, C., Buchmann, N., Frank, D., Papale, D., Rammig, A., Smith, P., Thonicke, K., van der Velde, M., Vicca, S., Walz, A., \& Wattenbach, M. (2013). Climate extremes and the carbon cycle. Nature, 500, 287-295.

Ripple, W. J., Smith, P., Haberl, H., Montzka, S. A., McAlpine, C., \& Boucher, D. H. (2014). Ruminants, climate change and climate policy. Nature Climate Change, 4, 2-5.

Rockström, J., Steffen, W., Noone, K., Persson, Å., Chapin, F. S., III, Lambin, E. F., Lenton, T. M., Scheffer, M., Folke, C., Schellnhuber, H. J., Nykvist, B., de Wit, C. A., Hughes, T., van der Leeuw, S., Rodhe, H., Sörlin, S., Snyder, P. K., Costanza, R., Svedin, U., Falkenmark, M., Karlberg, L., Corell, R. W., Fabry, V. J., Hansen, J., Walker, B., Liverman, D., Richardson, K., Crutzen, P., \& Foley, J. A. (2009). Planetary boundaries: exploring the safe operating space for humanity. Ecology and Society, 14(2), 32.

Siegel, K. R., Ali, M. K., Srinivasiah, A., Nugent, R. A., \& Narayan, K. M. V. (2014). Do we produce enough fruits and vegetables to meet global health need? PLoS ONE, 9(8), e104059. doi:10.1371/journal. pone. 0104059

Smith, P., Haberl, H., Popp, A., Erb, K.-H., Lauk, C., Harper, R., et al. (2013). How much land based greenhouse gas mitigation can be achieved without compromising food security and environmental goals? Global Change Biology, 19, 2285-2302.

Steffen, W. (2006). The arctic in an earth system context: from brake to accelerator of change. Ambio, 35(4), 153-159.

Stehfest, E., \& Bouwman, L. (2006). N2O and NO emission from agricultural fields and soils under natural vegetation: summarizing available measurement data and modelling of global annual emissions. Nutrient Cycling in Agroecosystems, 74(3), 207-228.

Stevens, G. A., Singh, G. M., Lu, Y., Danaei, G., Lin, J. K., Finucane, M. M., et al. (2012). National, regional, and global trends in adult overweight and obesity prevalences. Population Health Metrics, 10, 22.

Tilman, D., \& Clark, M. (2014). Global diets link environmental sustainability and human health. Nature, 515, 518-522.

Turner, B. L., Lambin, E. F., \& Reenberg, A. (2007). The emergence of land change science for global environmental change and sustainability. Proceedings of the National Academy of Sciences of the United States of America, 104, 20666-20671.

Wang, F. H., Dou, Z. X., Ma, L., Ma, W. Q., Sims, J. T., \& Zhang, F. S. (2010). Nitrogen mass low in China's animal production system and environmental implications. Journal of Environmental Quality, 39, $1537-1544$.

Vranken, L., Avermaete, T., Petalios, D., \& Mathijs, E. (2014). Curbing global meat consumption: emerging evidence of a second nutrition transition. Environmental Science and Policy, 39, 95-106.

Wang, F., Sims, J. T., Ma, L., Ma, W., Dou, Z., \& Zhang, F. (2011). The phosphorus footprint of China's food chain: implications for food security, natural resource management, and environmental quality. Journal of Environmental Quality, 40, 1081-1089.

Weinberger, K., \& Lumpkin, T. (2007). Diversification into horticulture and poverty reduction: a research agenda. World Development, 35 , 1464-1480. 
WHO/FAO. (2002). Diet, nutrition and the prevention of chronic diseases. Report of a joint WHO/FAO expert consultation, 28 January - 1 February 2002, Geneva, Switzerland (WHO Technical Report Series 916).

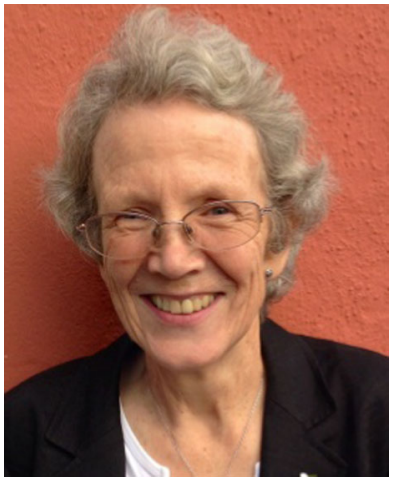

Margaret Gill Margaret Gill is the Chair of the Independent Science and Partnership Council of the CGIAR and also a Professor of Integrated Land Use at the University of Aberdeen. Previous posts have included Chief Scientific Adviser on Rural Affairs and the Environment in the Scottish Government, Chief Executive of the Macaulay Land Use Research Institute in Aberdeen and Chief Executive of Natural Resources International Ltd. Her research career was originally in ruminant nutrition, subsequently on the impacts of livestock systems on the environment before she moved into research management positions.

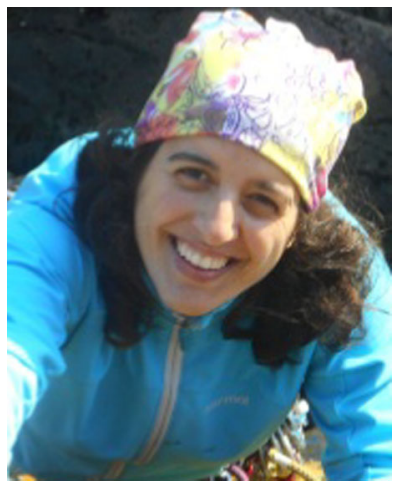

Diana Feliciano Diana works at the Environmental Modelling Group at the School of Biological Sciences at the University of Aberdeen and supports the Chair of the Independent Science and Partnership Council of the CGIAR in the planning and management of research strategies with respect to food security, poverty alleviation, improved health and nutrition, and management of natural resources in developing countries for the World Bank. Diana Feliciano holds a $\mathrm{PhD}$ in Geography from the University of Aberdeen, an MSc in Economics from the Portuguese Catholic University and a degree in Forest Engineering from the Technical University of Lisbon. Diana is an active participant and working group leader in FPS COST Action FP1201 Forest Land
Ownership Changes in Europe: Significance for Management and Policy (FACESMAP) and an adviser within the UNECE/FAO Forest Ownership Core Group.

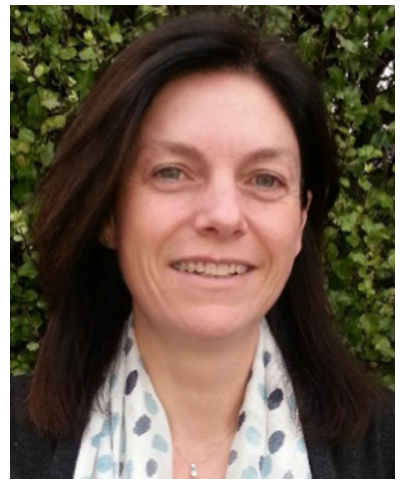

Jennie Macdiarmid Jennie Macdiarmid is a senior research fellow in Public Health Nutrition at the Rowett Institute of Nutrition and Health, University of Aberdeen, Scotland, UK. She holds a degree from the University of Surrey in Nutrition and Food Science and a $\mathrm{PhD}$ in Psychology from the University of Leeds. Her research interests include nutrition, health and the environmental impact of food choices within the context of healthy, sustainable diets.

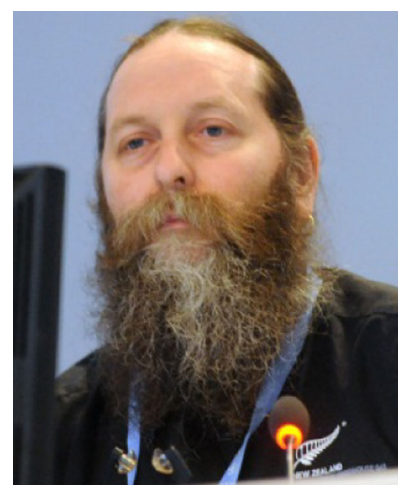

Pete Smith Pete Smith is the Professor of Soils and Global Change at the Institute of Biological and Environmental Sciences at the University of Aberdeen (Scotland, UK), Science Director of the Scottish Climate Change Cen$\mathrm{t} \mathrm{r}$ e of Ex p e r t i s e (ClimateXChange) and Director of Food Systems for the Scottish Food Security Alliance-Crops. He leads the University of Aberdeen multi-disciplinary theme on Environment \& Food Security. He is a Fellow of the Society of Biology, a Rothamsted Research Fellow, a Research Fellow of the Royal Society (London; 2008-2013), and a Fellow of the Royal Society of Edinburgh. 